\title{
CORPORATE GOVERNANCE, CONTROL AND CORPORATE PERFORMANCE
}

\author{
Mahama Wayo (PhID. Finance) \\ (Head of Finance, Tamale Polytechnic, Ghana) \\ Osman Chilala \\ (Lecturer, Bolgatanga Polytechnic, Ghana)
}

\begin{abstract}
The paper looked at the definitions of corporate governance as it pertains to the management of organizations today as a control and reporting mechanism. The need for corporate governance as a result of the "agency" problem, where the owners of corporations cede the management and operations of these organizations to other groups in return for value and stewardship. The paper also dealt with the role of corporate governance in corporate performance and control, and the powers that the Board of an organization can exercise through its sub-boards. Earning as a key corporate performance indicator and the manipulation of earnings by top management of corporations as a result of their compensation and incentives is also discussed in this paper. It is not uncommon for the executives of corporations to manipulate earnings upwards once their compensation and incentives are tied to the earnings. This interest-based act of the executives is checked by the Audit Committee as a sub-board to the main board. The role of audit committees and in particular with regards to earnings manipulation and corporate performance is discussed in this paper. The paper concluded by indicating that to ensure the delivery of value by the executive of an organization, it is imperative that necessary and not excessive controls are put in place.
\end{abstract}

\section{Corporate Governance, Control and Corporate Performance}

\section{Introduction}

"Corporate governance is the system of checks and balances, both internal and external to companies, which ensures that companies discharge their accountability to all their stakeholders and act in a socially responsible way in all areas of their business activities" (Solomon and Solomon 2010, p.14).

Omane-Antwi (2009, p.590) defines corporate governance as: "a means of ensuring due and adequate control over the strategy and direction of an organization and the stewardship, use and disposition of assets- both financial and non-financial in achieving its key objectives."

This definition highlights corporate governance as a function of leadership and direction; risk management, control and reporting. Corporate governance is seen as a solution to the 'agency' problem as companies go public expanding the size of ownership. It becomes necessary to cede the management of these companies to others than the shareholders. This group is called the Board of Directors and, management. This is a stewardship role given to the Board and the Management by owners of the companies. As a result of the 'Agency Theory', which requires the separation of corporate management and owners, there is the need to provide protection to the owners (shareholders) through the Board; because managers sometimes may not behave in the interest of the shareholders (Fama and Jensen, 1983; Jensen and Meckling, 1976). When management decisions do not fulfill the requirements of good governance, the interests of the owners of the companies usually suffer. In other words, there are often conflicting goals of the Board, Management, and the Owners. It has been seen where owners 
believe that the Board and the Management are maximizing their bonuses instead of pursuing the shareholders goal of value maximization (Cheffins, 2009).

This conflicting goals of maximization resulted in the agency problem which, subsequently led to oversight supervision of the management (agents) of companies. Boards of public companies generally have to exercise independent oversight to ensure that managers of companies were accountable to shareholders. However, boards were sometimes negligent in their oversight responsibilities which led to manipulation, fraud, or the collapse of some companies. According to Cheffins (2009) Penn Central, a railway company which diversified into pipelines, hotels, industrial parks and commercial real estate, collapsed in 1970 due to personality clashes, management inefficiencies and lax board oversight.

\section{The Role of Corporate Governance in Corporate Performance}

Corporate governance therefore is to provide the needed checks on the management of companies. According to Lacker and Tayan (2014), the instance of corporate governance is as a result of individuals working in an organization seeking to achieve their personal interests as against the interest of the organization. How these checks are instituted and operated is still questionable given the failure of companies today. Moreover, the Boards typically receive their information from management. Often it is seen that as information rises in an entity, it is often filtered and repackaged at each level. Hence a concern is just what information is the Board receiving. Corporate governance has become a prominent global issue today because of the massive business failures beginning from the 1980 s to the credit meltdown in 2008. Bruce (2012, p.18) writing in the Chartered Institute of Management Accountants Journal, "Financial Management" states that, "...efforts to improve corporate governance in the wake of the financial crisis should have financial reporting at their heart." This underscores the role of corporate governance in a corporate entity's financial management. The critical issue in corporate governance today is the optimal level of governance system, and how the structures of an organization should be put in place to ensure efficient decision-making in the interest of shareholders (Lacker and Tayan, 2014). In view of this, organizations are strengthening their controls and policies to check malfeasance and also to review decisions by the Executive.

Omane-Antwi (2009) indicates that the need to meet stiff business competition and, creating confidence in investors while attracting potential investors has given rise to the need to strengthen corporate governance. Also, the arbitrary widening gap between compensation for executives relative to the performance of businesses equally called for robustness in corporate governance today. The Ghanaian Securities and Exchange Commission's Manual on Corporate Governance in Ghana (2000, p.1) sees corporate governance as the:

...manner in which power is exercised in the management of economic and social resources for sustainable human development. It is a vital ingredient in the maintenance of a dynamic balance between the need for order and equality in society, the efficient production and delivery of goods and services, accountability in the use of power, the protection of human rights and freedoms and maintenance of an organized corporate framework which each citizen can contribute fully towards finding innovative solutions to common problems. More specifically, corporate governance refers to the manner in which the power of a corporation is exercised in the stewardship of a corporation's total portfolio of assets and legal rights of all stakeholders in the context of the mission.

This assertion of corporate governance focuses on the efficient management of organization's resources and the benefits derived by the stakeholders. The power entrusted to the board and how this 
is exercised in the interest of the stakeholders and, how the organization's contribution to the economic growth and development also benefits the nation.

To this end, the Ghanaian Securities and Exchange Commission (SEC) made it mandatory for public companies to add in their annual reports, a corporate governance report. According to OmaneAntwi (2009), the corporate governance report submitted to the SEC should contain information on the key activities, committees of the Board of Directors, especially audit committees and the operational standards of the company indicating transparency and accountability to the public.

The Ghanaian SEC in ensuring that companies uphold the tenet of corporate governance sees good corporate governance to include:

$i$. The management of the relationship between a corporate body's management, its board, its shareholders and the other stakeholders.

ii. The management of risk and the minimization of the effects of commercial disadvantage.

iii. Bringing more transparency to bear on the decision-making processes of the company.

$i v$. Encouraging the use of resources in a more transparent manner.

$v$. The provision of proper incentives for the Board and Management to pursue objective that is in the interest of the corporate body and shareholders.

vi. The provision of the structure through which the objectives of the company are identified and the monitoring of the means used to attain these objectives including the monitoring of performance in Ghana Incorporated (Manual on Corporate Governance, 2000, p.1-2).

Corporate governance (Boards) plays a significant role in corporate financial management. The involvement of the Board starts with the approval of the company's formation agreement, bye-laws, internal operating authorities, registration documents, annual budget, and capital expenditure undertaken by the company. This is in line with financial management and audit procedures in ensuring transparency and accountability of managers to shareholders.

The Board also has a responsibility by fulfilling regulatory requirements of putting up an audit committee to advice on audit matters. Financial statements of a company are signed by the Chairman of the Board and hence that party is responsible for the statements.

Klapper and Love (2002) indicates that better corporate governance is correlated with better operating performance and market valuation. All other things being equal, the higher the performance, the higher the value of the company. Cornett, McNutt and Tehranian (2009) and Shen and Chih (2007) has identified corporate governance mechanisms as having effect on firm financial performance. They contend that independent outside directors' in most cases have wide range of experience which they could bring to bear on the firm. The more the number of outside directors, who are truly independent, the greater the control and monitoring exerted on management (Cornett, McNutt and Tehranian, 2009). Cornett et al. (2009) further argue that studies have consistently found better stock returns and operating performance when outside directors hold a significant percentage of board seats. This assertion is supported by $\mathrm{Hsu}$ and $\mathrm{Wu}$ (2009), that the more inside directors, the more likely a company may fail. The implications are that independent outside directors will be less involved in inflating earnings, and with the experience they have, they can more effectively oversee the activities of management which consequently boosts the performance of the firm.

Cornett et al. (2009) and Shen and Chih (2007) further contend that small boards are more effective in monitoring management than large boards. Therefore, it can be argued that there is a relationship between the size of a board and earnings management. The larger the board the more likely that monitoring will not be effective, hence the occurrence of earnings management, and the smaller 
the board the less likely management will engage in earnings management due to strict monitoring and control.

Companies that have good corporate governance tend to have effective boards that ensure strict control and monitoring and therefore engage in less earnings management. Corporate governance therefore plays a central role in corporate financial management. And good corporate governance must be exhibited by boards to ensure effective and efficient financial management of companies.

\section{Earnings Manipulation and Corporate Performance}

Various literature address the issues concerning earnings manipulation by firms. The motives for manipulation of earnings are varied and the culprits of this act are usually the managers or executives of a firm. In manipulating earnings, firms present spurious financial statements by inflating and deflating some of the variables that go into the computation of earnings.

Beneish (1999, p. 3) defines earnings manipulation as: “...an instance where management violates Generally Accepted Accounting Principles (GAAP) in order to beneficially represent the firm's financial performance." From the definition is the phrase 'beneficially represent; its use implies that management tends to benefit from earnings manipulation and therefore have the incentive to get involved in earnings manipulation. Beneish (1999) argues that firms with poor prospects are the likely candidates to indulge in earnings manipulation.

Cornett et al. (2009) posits that incentive-based compensation has a large impact on financial performance as measured by reported earnings. They contend further that when the Chief Executive Officer's compensation is tied to the price of the firm's stock (either through compensation in the form of stock or stock options), the firm's value increases. This assertion is in consonance with that of Peng and Roell (2006) that when performance contracts are short-term there is a greater tendency for the manipulation of share prices and earnings to occur.

Peng and Roell (2006) state that the incentive for manipulation of earnings is related to the contract structure; whether the contract is short-term or long-term. That the more short-term the contract, the more likely management is to inflate earnings.

According to Feng, Ge, Luo and Shevlin, 2010), Chief Executive Officers (CEOs) of manipulation firms tend to have significantly higher incentives and power than CEOs of better controlled firms. They argued that Chief Financial Officers (CFOs) can get involved in earnings manipulation for their immediate personal financial gains as contained in their equity compensation. Also, CFOs may be pressured by CEOs to manipulate earnings.

Pressure from the Board for the Executive to sustain or attain a certain level of performance can result in earnings manipulation by firms. A clear example is Enron Corporation which was engulfed in major contractual incentives in the form of debt and stock options that exerted great pressure on its management to sustain and improve performance (Catanach Jr. and Catanach, 2003). They indicated that Enron's financial performance dipped in 1997 to 2000 with financial indicators such as income before extraordinary items (IBE), comprehensive income (CI) and free Cash flow (FCF) "uncoupling." The share price of Enron fell drastically during this period as a result of the company's engagement in earnings manipulation. It should be noted that Jim Chanos, CEO of Kynikos, shorted Enron for a sustained period before its failure in December 2001. Chanos' admits to making over \$1 billion U.S. shorting Enron. For some period of time, there was a verbal ping pong match taking place weekly on the Op-Ed pages of The Wall Street Journal in 2001. One week, Ken Lay, CEO of Enron would write the only reason Enron stock was diving was because Chanos' was short selling the stock. The next 
week Chanos' would write the only reason I am shorting the stock is because I believe it is highly overvalued. Today it is known who was right.

Earnings manipulation has adverse consequences on the performance of firms that engage in this exercise.

Aflatooni and Nikbakht (2010) hypothesized that in the long-run, market response to firms that engaged in income smoothing and earnings management is negative. It was also found that firms involved in income smoothing to avoid losses have significantly lower long-run returns and abnormal returns than firms that do not.

\section{Audit Committees and Manipulation of Earnings}

According to Vera-Munoz (2005, p.3), the Sarbanes -Oxley Act of 2002, defines Audit Committee as:

"... a committee (or equivalent body) established by and amongst the board of directors of an issuer for the purpose of overseeing the accounting and financial reporting processes of the issuer, and audits of the financial statements of the issuer."

Vera-Munoz (2005) further states that the Sarbanes-Oxley Act attempts to increase the responsibilities and authority of Audit Committees, and also raise the membership requirements and composition of important committees to include more independent directors. However, Hoitash and Hoitash (2007, p.1) argued that prior to the Sarbanes-Oxley Act, Audit Committees had limited responsibilities which entailed advisory role to management and the external auditor on the audit and preparation of financial statements.

Audit Committees are carved out of the Board or are sub-committees of the Board with independent professional and more experienced members who have the potential of bringing their background to bear on the organization's operations. To ensure high performance of the organization, members of audit committees are required to exhibit maximum professional qualities and independence in executing their roles without interfering in the functions of management of the organization.

The Sarbanes-Oxley Act, according to Lander (2004) requires that every member of the Audit Committee must be 'independent'. By being independent means that a director may not have accepted any direct or indirect compensation from the company or its subsidiaries, other than compensation for service as a director, and may not be an 'affiliated person' of the company. That the Audit Committee must have the authority and responsible for hiring, compensating and retaining the company's independent auditor. And also the Committee must oversee the auditor's work in the preparation or issue of any audit report.

Omane-Antwi (2009), describes Audit Committees as a concept whereby a listed company establishes a committee composed of outside directors or non-executive officers of the company to act as a liaison between the Board of Directors and the company's statutory auditors and in some cases the internal auditors.

Audit Committees in performing their role provide an avenue for external auditors to work by preventing any impediments which the executives of a company may put across. According to Sori, Abdul Hamid and Nassir (2006), the setting up of Audit Committees is intended to prevent corporate fraudulent reporting. Among the qualities of financial reports are objectivity, reliability, and credibility; the existence of an effective Audit Committee ensures these qualities and confidence in financial reports. In some instances, Audit Committees are given the responsibility to appointment and fix the remuneration of auditors thereby ensuring their independence from the management of the company. 
This enables external auditors to report any possible manipulation of earnings by management to the Board as it is contained in the audit report.

Audit Committees also review the accounting policies that a company may adopt ensuring that management does not adopt policies that could result in the manipulation of earnings and other financial information to their advantage. Consequently, Audit Committees will review the evaluation of internal controls by the external auditors' and also ensure prompt response to issues raised in the audit report.

Cai, Hillier, Tian and Wu, ( 2011), state that regulatory authorities the world over today have placed the Audit Committees at the heart of any corporate governance system with its oversight responsibilities for corporate reporting, risk management and internal controls.

McMullen (1996) and Dechow et al. (2010) provided evidence to suggest that the instance of an Audit Committee in a company ensures a monitoring environment that tends to reduce aggressive reporting.

Due to the pervasiveness of earnings manipulation/management regulators have opened their eyes wide to curb this menace. Loomis (1999), states in his article in "Fortune Magazine," that earnings management is rampant and Chief Executive Officers (CEOs) see earnings management as a tool to ensure that their firms meet earnings expectations.

Boards are responsible for financial statements and therefore assume the responsibility for any fraudulent reporting. It therefore implies that boards must constrain earnings manipulation. The formation of the Blue Ribbon Panel by the Public Company Accounting Oversight Board (PCAOB, 2002) that is an independent private sector group that oversees the self-regulatory programmes of the U.S. Securities and Exchange Commission (SEC) Practice Section of the American Institute of Certified Public Accountants; placed responsibilities on company boards to deal with earnings manipulation/management. Among other things, the Blue Ribbon Panel recommends that board members who serve on Audit Committees should be financially sophisticated to help detect earnings management. The Sarbanes-Oxley Act, requires that at least one member of an Audit Committee should be a financial expert to better understand and analyze financial statements of a company. This is in line with the Blue Ribbon Panel requirements that board members on Audit Committees should be financially sophisticated.

Managers mostly use accrual accounting to manipulate earnings. Xie, Davidson and DaDalt (2001), contend that the nature of accrual accounting tends to give mangers a great deal of discretion in determining actual earnings a firm reports in any given period. Where mangers' compensation is based on the company's financial performance, earnings manipulation/management often becomes pervasive. Manipulated financial information (earnings) misleads investors who rely on stock prices to make investment decisions. However, capital markets adjust stock prices using financial information.

Audit Committees therefore must play a greater role in mitigating earnings manipulation/management to instill confidence in stakeholders. Xie, Davidson and DaDalt (2001), posit that Audit Committees should be responsible for monitoring the financial performance and reporting of companies. They contend further that, having a considerable number of outside corporate directors and those with experience strengthens the Audit Committee's ability to monitor properly the financial performance of a company thereby reducing earnings manipulation. They contend further that the composition of an audit committee where some members are financial experts is associated with reduced level of earnings management, and may be a better financial monitor. Also, the more frequent the Board and the Audit Committees meet, the less likely the level of earnings manipulation as they provide a check on management. 
However, Omane-Antwi (2009) argued that the Audit Committee concept can lead to conflict and misunderstanding in a company if objectives are not well defined. Also setting up and maintaining Audit Committees is costly and expensive.

\section{Conclusion}

Corporate governance has become inevitable in the management of organizations today due to the conflicting interests of shareholders and executives. The difficulty and the question are whose interest is supreme and how it should be achieved? Organizations try to institute numerous and excessive controls to prevent malfeasance from the executive in their quest to achieve their interest. However, it is imperative to put in place necessary controls and not just excessive controls to ensure that the executive deliver value for the organization. Necessary controls will serve as a check on the excesses of the executive in terms of their incentives and self-interest. The instance of audit committees and their composition and, the experience of the members and the frequency of meetings, also place some amount of checks on the executive thereby safeguarding the manipulation of earnings and deception in corporate financial reporting.

\section{Selected References}

I. Aflatooni, A., Nikbakht, Z. (2009). Income smoothing, real earnings management and long-run stock returns. Business Intelligence Journal. 3(1) vol. 3, Issue 1.

II. Beneish, M. D. (1999). The detection of earnings manipulation. Indiana University, Kelley School of Business, working paper series. Retrieved May 30, 2010 from http://www.baner.uh.edu/swhisenant/beneishearningsmgmt score.pdf

III.Bruce, R., (2012). Efforts to improve corporate governance in the wake of the financial crisis should have financial reporting at their heart. Financial Management. Chartered Institute of Management Accountants. Also available at www.fm-magazine.com

IV. Cai, C. X., Hillier, D., Tian, G., Wu, Q. (2011). Do audit committees reduce the agency costs of ownership structure? Retrieved November 10, 2012, from www.ssrn.com

V. Catanach Jr. A. H, Catanach, R.S., (2003). Enron: A financial reporting failure? Retrieved May 30, 2010 from www.ssrn.com

VI.Cheffins, B. R. (2009). Did corporate governance "fail" during the 2008 stock market meltdown? The case of the S\&P 500, Working Paper. Retrieved July 2, 2012, from http://ssrn.com/abstract=1396126

VII.Cornett, M. M., McNutt, J. J., Tehranian, H. (2009). Corporate governance and earnings management at large U.S. bank holding companies. Journal of Corporate Finance 15 (2009), 412-450.

VIII. Dechow, P. M., Hutton, A. P., Kim, J. H., Sloan, R. G. (2010). Detecting earnings management:

A new approach. Retrieved from http://ssru.com/abstract=1735168

IX. www.jsture. org $/$ discover $/ 10.2307 / 2491102$ ?uid=37380728uid=20uid=40sid=4102564553863

X. Fama, E. F., Jensen, M. C. (1983). Agency problems and residual claims. Journal of Law and Economics, Vol. XXVI (June, 1983). Retrieved August 20, 2013, from www.jstor.org $/$ discover $/ 10.2307 / 725105$ ?uid=3738072uid=28uid=48sid=21102539511501

XI.Feng, M. Ge, W., Luo, S., Shevlin, T., (2010). Why do CFOs become involve in material accounting manipulation. Retrieved February 2, 2011, from ssrn.com 
XII.Hoitash, R. Hoitash, U. (2007). The role of audit committees in managing relationships with external auditors after SOX: Evidence from the US. Retrieved October 29, 2011. Also available at http://ssrn.com/abstract=1312024

XIII. Hsu, H-H, Wu, Y-H (2009). Board composition audit committee structure, 'Grey Directors' and the incidence of corporate failure in the U. K. Available at http://ssrn.com/abstract=1532997

XIV.Jensen, M. C., Meckling, W. H. (1976). Theory of the firm: Managerial behavior, agency costs and ownership structure. Journal of Financial Economics, 3 (1976) 305-360. Retrieved August 20, 2013, from www.sciencedirect.com/science/article/pii/0304405x7690026x

XV. Klapper, L. F., Love, I. (2002). Corporate governance, investor protection and performance in emerging markets. Retrieved August 20, 2013, from www1.fee.uva.nl/fin/conference/budapstCorporateGovernance/1multipart_xF8FF_2_CLSA_fina 1.pdf

XVI.Lacker, D. F., Tayan, B. (2014). Corporate governance according to Charles T. Munger. Rock Center for Corporate Governance.

XVII.Lander, G. P. (2004). What is sarbanes-oxley? New York. McGraw-Hill.

XVIII. Loomis, C. (1999). The crackdown is here. Fortune, 1999, August 2, 140:75-92.

XIX. McMullen, D. A. (1996). Audit committee performance: An investigation of the consequences associated with audit committees. Auditing: A Journal of Practice and Theory 14, (Spring): 87103.

XX. Omame-Antwi, K. B. (2009) Auditing theory and practice (the auditing compendium). Tema, Digibooks Ghana Limited.

XXI.Peng, A. L., Roell, A. (2007). Executive pay and shareholder litigation. Retrieved January 15, 2012, from rof.oxfordjournals.org/content/12/1/141.abstract

XXII. Securities and Exchange Commission. (2000). Corporate governance, gudielines on best practices. Ghana

XXIII. Shen, C-H., Chih, H-L. (2007). Earnings management and corporate governance in Asia's Emerging Markets. Retrieved March 1, 2011, from www.ssrn.com

XXIV.Solomon, J., Solomon, A. (2010). Corporate governance and accountability. African Reprint. New Delhi. Wiley \& India Pvt. Limited.

XXV. Sori, Z. M., Hamid, M. A. A., Nasir, A. M. (2006). Attributes of an effective audit committee: Evidence from an emerging capital market. Retrieved from www.ssrn.com

XXVI.Vera-Munoz, S. C. (2005). Corporate governance reforms: Redefined expectations of audit committee responsibilities and effectiveness. Retrieved July 18, 2011, from www.ssrn.com

XXVII.Xie, B., Davidson III, W. N., DaDalt, P. J. (2001). Earnings management and corporate governance: The roles of the board and the audit committee. Retrieved June 20, 2011, www.ssrn.com 